\title{
COMMENTARY ON THE JUDGMENT OF THE PROVINCIAL COURT OF BARCELONA OF 29 MAY 2020 [CARRIAGE OF GOODS BY SEA FROM ECUADOR TO SPAIN UNDER A BILL OF LADING] [ES:APB:2020:3847A]
}

\author{
COMENTARIO A LA SENTENCIA DE LA AUDIENCIA \\ PROVINCIAL DE BARCELONA DE 29 DE MAYO DE 2020 \\ [TRANSPORTE DE MERCANCÍAS POR VÍA MARÍTIMA \\ DESDE ECUADOR A ESPAÑA EN RÉGIMEN \\ DE CONOCIMIENTO DE EMBARQUE] [ES:APB:2020:3847A]
}

\author{
JoNATAN ECHEBARRIA FERNÁNDEZ \\ Lecturer in Law, Academic Visitor Programme Director \\ The City Law School; City, University of London
}

Recibido: 02.12.2020/ / Aceptado: 21.12.2020

DOI: https://doi.org/10.20318/cdt.2021.5995

\begin{abstract}
The commentary on the judgment of 29 May 2020 of the Provincial Audience of Barcelona No. 15 on the appeal filed against the Order of 4 June 2019 of the Commercial Court No. 4 of Barcelona provides an analysis of the contradictory doctrine that some Spanish courts have followed regarding the conveyance of the Bill of Lading (B/L), especially regarding the jurisdiction clauses of other European Union (EU) courts, included in this document, in favour of the third party endorsee, who has not been required to sign the document since the Spanish Act on Maritime Navigation (SAMN) 14/2014 of 24 July 2014 was passed. The requirements set out by the European legislator and the doctrines of the Court of Justice of the European Union (CJEU) and some Spanish courts diverge in respect of the grounds of this judgment. While the law applicable to the formal and substantive validity of those agreements is set out by Article 25 of the Brussels I Regulation (recast), the consent by the contracting parties relies on national law. The Spanish Supreme Court has still not rendered any judgment that specifies the efficacy of the jurisdiction agreement over a B/L endorsee in case of cargo claims since the approval of the SAMN. Thus, discrepancies remain in this contentious area.

Keywords: Jurisdiction agreements, title to the goods, applicable law to the conveyance of the Bill of Lading (B/L) to a third party endorsee, Brussels I Regulation (recast), Spanish Organic Law on the Judiciary, Spanish Act on Maritime Navigation, CJEU.

Resumen: El comentario a la sentencia de 29 de mayo de 2020 de la Audiencia Provincial de Barcelona (Sección 15) sobre el recurso de apelación interpuesto contra la Auto de 4 de junio de 2019 del Juzgado de lo Mercantil número 4 de Barcelona ofrece un análisis de la doctrina contradictoria que han seguido algunos tribunales españoles en relación con la transmisión del conocimiento de embarque $(\mathrm{B} / \mathrm{L})$, especialmente en lo que respecta a las cláusulas de jurisdicción a favor de otros tribunales de la Unión Europea (UE) incluidas en dicho documento, al tercero endosatario que no firmó dicho documento, desde la aprobación de la Ley de Navegación Marítima (LNM)14/2014 de 24 de julio de 2014. Los requisitos establecidos por el legislador europeo y las doctrinas del Tribunal de Justicia de la Unión Europea (TJUE) y de ciertas decisiones de los tribunales españoles divergen con respecto a los fundamentos de derecho de esta sentencia. Si bien la ley aplicable a la validez formal y sustantiva de
\end{abstract}


dichos acuerdos se establece en el artículo 25 del Reglamento Bruselas I bis, el consentimiento de las partes contratantes se rige por la legislación nacional. El Tribunal Supremo español aún no ha dictado sentencia que especifique la eficacia del acuerdo de jurisdicción sobre un endosatario del conocimiento de embarque en caso de reclamaciones por daños a la mercancía desde la aprobación de la LNM. Por lo tanto, persisten discrepancias en esta polémica área.

Palabras clave: Acuerdos de jurisdicción, titularidad de las mercancías, ley aplicable a la transmisión del conocimiento de embarque $(\mathrm{B} / \mathrm{L})$ al tercero endosatario, Reglamento Bruselas I bis; Ley Orgánica del Poder Judicial, Ley Española de Navegación Marítima, TJUE.

Summary: I. Introduction. II. Shipping documents under English and Spanish law: a comparative perspective. A) Negotiable transport documents. B) Non-negotiable transport documents. III. Facts. IV. Grounds for appeal. V. Grounds of the decision. 1. Party autonomy in contracts for the carriage of goods by sea. 2. Validity of the parties' consent to be bound by a jurisdiction agreement included in a B/L. 3. Effectiveness of the conveyance of $B / L$ clauses to third parties under the CJEU's doctrine. 4. Divergence from the CJEU's doctrine regarding the rights and obligations of the third party endorsee to the $\mathrm{B} / \mathrm{L}$ containing a jurisdiction agreement negotiated between the shipper and the carrier. 5. Applicability of the restrictive approach to the case. VI. Final remarks: a wrongful doctrine on the prevalence of Articles 468 and 251 SAMN over Article 25 of the Brussels I Regulation (recast).

\section{Introduction}

1. Carriage of goods by sea is one of the most litigious areas of law, since it is the main means of transport chosen for the vast majority of world trade. While the charterer agrees with a shipowner on the hire of a vessel for a period of time or the freight payable for a specific voyage, a freight forwarder, or as in the analysed judgment of the Provincial Court of Barcelona No. 15, a shipper, agrees the transport of cargo with a carrier. The 'lex mercatoria' has developed the concept of negotiable instruments that may alter the title to the goods carried onboard a ship. ${ }^{1}$ The subject of this judgment relates to the rights and obligations entrusted to the holder of a Bill of Lading $(\mathrm{B} / \mathrm{L})$, the transport document that constitutes a document of title to the goods but not a contract for the carriage of goods by sea, although it serves as a proof of it. ${ }^{2}$

2. Uniform international instruments applicable to the $\mathrm{B} / \mathrm{L}$, namely the Hague-Visby Rules ${ }^{3}$ (ratified by Spain), do not define it. The B/L follows the contract for the carriage of goods by sea and it can be said that it represents no more than a receipt for the charterer, and serves as evidence of the previous contract (booking) between the carrier and the shipper of the goods for the endorsee. ${ }^{4}$ It serves as proof

\footnotetext{
${ }^{1}$ Unlike a cheque, the endorsee does "not get a better title than the assignor" and technically, a negotiable B/L is similar to a transferrable and non-negotiable cheque; see the leading English case Lickbarrow v Mason (1794) 5 T.R. 683; D. FoxTON, H. Bennetr, S. Berry, C. Smith, and D. WALSh, Scrutton on Charterparties and Bills of Lading, Sweet \& Maxwell Ltd, 2019 , at [10-001].

${ }^{2}$ C. Llorente Gómez de Segura, "V. Contratos internacionales. El contrato de transporte marítimo de mercancías", in A.-L. Calvo Caravaca and J. Carrascosa González (eds.), Derecho del Comercio Internacional, Colex, 2012, p. 953; I. ANTÓN JuÁREZ, "Choice of court agreements: the hidden details of the art. 25 of Brussels I Bis Regulation disclosed by the Supreme Court", in A.-L. Calvo Caravaca and J. Carrascosa González (eds.), El Tribunal Supremo y el Derecho Internacional Privado. Colección Derecho y "Letras" Vol 1, No 1, Rapid centro color, 2019, pp. 232-235; Foxton et al. (note 1), at [5-007].

${ }^{3}$ International Convention for the Unification of Certain Rules of Law Relating to Bills of Lading signed at Brussels on 25 August 1924 ('the Hague Rules') 51 Stat 223, Vol. 120 LNTS, p. 155, amended by the Protocol to Amend the International Convention for the Unification of Certain Rules of Law Relating to Bills of Lading signed at Brussels on 23 February 1968 ('the Visby rules') Vol. 1412 UNTS, p. 121, and the last Protocol amending the Hague-Visby Rules signed at Brussels on 21 December 1979 ('SDR Visby Protocol') vol. 1412 UNTS, p. 146.

${ }^{4}$ A.-L. Calvo Caravaca and J. Carrascosa González, "Competencia judicial internacional y Derecho de los negocios internacionales", in A.-L. Calvo Caravaca and J. Carrascosa González (eds.), Derecho Internacional Privado, Vol. II, 18 ${ }^{\text {th }}$
} 
of the reception of the goods, as well as their state and condition, by the carrier. Moreover, it constitutes a document of title and entrusts the party bearing it with the disposition of property, unlike the sea waybill. The latter is a non-negotiable document that does not entrust the holder with a title to the goods. Article 250(1) of the Spanish Act on Maritime Navigation 14/2014 (SAMN) ${ }^{5}$ distinguishes between B/ Ls 'to the bearer, to the order or nominative'.

\section{Shipping documents under English and Spanish law: a comparative perspective}

3. The nature of negotiable and non-negotiable transport documents must be introduced since it is paramount in order to analyse the judgment of the Commercial Court of Barcelona No. 15 of 29 May $2020 .^{6}$ The title to the goods is the first key issue to consider by stressing the differences between these documents. An introduction to the negotiable B/Ls is necessary: the carrier delivers the goods to, and can be sued by, a party "who is not always identified on the $B / L$ " when a $\mathrm{B} / \mathrm{L}$ is issued to the 'bearer', 'to the order of the shipper' or 'a named consignee' other than the shipper.'

\section{A) Negotiable transport documents}

4. The first type of $\mathrm{B} / \mathrm{L}$ ' names the bearer as the consignee'. It does not require endorsement by cargo interests but its transfer "endows the holder with rights of suit against the carrier". ${ }^{8} \mathrm{The} \mathrm{B} / \mathrm{L}$ holder can be the buyer of the cargo, a bank financing the purchase to the buyer or any other party. A $\mathrm{B} / \mathrm{L}$ issued 'to the bearer' is transmitted 'by delivery' according to Article 250(2) SAMN, and must be presented by a third party who acquired it 'in good faith and without gross negligence' to receive the cargo, according to Article 545 of the Spanish Code of Commerce, ${ }^{9}$ under which 'bearer securities shall be transmissible by delivery of the document' ${ }^{10}$

5. The shipper's 'order' $\mathrm{B} / \mathrm{L}$ can be made "to the order", "to the shipper's order" or "to the shipper's name or order" in respect of a consignee. The shipper instructs the carrier that will carry the goods subject to the latter's "a priori attornment" or "acknowledgement". ${ }^{11}$ The person to whom goods are to be delivered "physically presents it for delivery of the goods at the agreed discharge port". ${ }^{12}$ The $\mathrm{B} / \mathrm{L}$ to the 'order of a named consignee' other than the shipper (often the buyer of the goods) who can endorse it (usually "on the reverse" side) to a subsequent buyer or leave it blank facilitates the collection of the goods by the consignee to whom the $\mathrm{B} / \mathrm{L}$ is transferred before surrendering it at the port of discharge. ${ }^{13}$

ed., Comares, 2018, p. 762; ANTÓN JuÁREZ (note 2), pp. 232-235.

${ }^{5}$ Spanish Act 14/2014 of 24 July 2014, on maritime navigation (Official State Gazette No. 125 of 26 May 2015).

${ }^{6}$ ES:APB:2020:3847A.

${ }^{7}$ C. Debattista, "Cargo claims and Bills of Lading", in Y. BaAtz, Maritime Law, Informa Law from Routledge, 2020, pp. $183-187$.

${ }^{8}$ Ibid., pp. $183-187$.

${ }^{9}$ Spanish Royal Decree of 22 August 1885 (Official Gazette Nos. 298 to 328, from 16 October to 24 November 1885), last modified by the Law 11/2018, of December 28, 2018 amending the Commercial Code, the revised Capital Companies Law approved by Legislative Royal Decree 1/2010, of 2 July 2010 and Audit Law 22/2015, of 20 July 2015, as regards non-financial information and diversity; moreover, the third book of the Spanish Commercial Code was repealed by the SAMN along with other laws on ship mortgage and other subjects.

${ }^{10}$ J. P. Rodríguez Delgado, El periodo de responsabilidad del porteador en el transporte marítimo de mercancías. De Bruselas a Rotterdam, PhD thesis, University Carlos III, 2015, p. 174.

${ }^{11}$ Debattista (note 7), pp. 183-187.

${ }^{12}$ Ibid., pp. 183-187.

${ }^{13}$ Alternatively, a B/L to the order of a bank may finance the purchase of the goods, usually by the buyer, under a letter of credit regulated by the International Chamber of Commerce's UCP 600 (Uniform Customs \& Practice for Documentary Credits). The charterer has the right to sue the carrier as well as the lawful holder of the $\mathrm{B} / \mathrm{L}$, i.e. the last buyer to whom the $\mathrm{B} / \mathrm{L}$ is endorsed in a chain of sales of goods; DeBATtista (note 7), pp. 183-187. 


\section{B) Non-negotiable transport documents}

6. The non-negotiable documents serve as a receipt of the goods and are proof of the contract of carriage but fail to provide for the title to the goods. Sea waybills and 'straight' or 'non-transferrable' $\mathrm{B} / \mathrm{Ls}$ do not require any transfer or endorsement of the $\mathrm{B} / \mathrm{L}$ by the shipper to the buyer but the verification of the buyer's identity by the carrier at the designated port of discharge. ${ }^{14}$ The first identifies the party entitled to sue the carrier (the buyer or any other consignee) and "to whom the goods are delivered [...] when the $B / L$ is issued" (e.g. intra-company shipments). ${ }^{15}$ The consignee is not obliged to present the document at the port of discharge under Spanish law according to Article 271 SAMN: "when the carrier delivers a sea waybill stating the consignee, the latter shall be entitled to delivery of the goods at destination without the need to produce the document'. These are not considered documents of title under Article I(b) of the Hague and Hague-Visby Rules. ${ }^{16}$ Article 250(2) SAMN sets out that B/Ls 'to the order' are transferred by endorsement.

7. The 'straight' or 'non-transferrable B/L' ('nominative' $\mathrm{B} / \mathrm{L}$ under the $\mathrm{SAMN}$ ) is "not made out to the bearer or anyone's order" and secures that the cargo is not sold in transit. However, the shipper can change the name of the consignee and instruct the carrier at any time before reaching the port of destination. ${ }^{17}$ Moreover, the buyer is left with no action against the carrier but can sue the shipper under the contract for the sale of goods. ${ }^{18}$ The carrier can be sued by the shipper and the buyer. ${ }^{19}$ Distinguishing between 'straight' or 'to the order' B/Ls is not easy, especially when the standard terms on the reverse of the $\mathrm{B} / \mathrm{L}$ allow for both possibilities. ${ }^{20} \mathrm{~A}$ contentious issue discussed by the House of Lords in the Rafaela $S$ judgment, ${ }^{21}$ regarding non-negotiable straight $\mathrm{B} / \mathrm{Ls}$, is the applicability of the Hague-Visby Rules to them. Straight $\mathrm{B} / \mathrm{Ls}$ are considered "B/Ls under Article $\mathrm{I}(\mathrm{b})$ of the Hague and Hague-Visby Rules". ${ }^{22}$ However, these are considered a $\mathrm{B} / \mathrm{L}$, a 'similar document of title' to the $\mathrm{B} / \mathrm{L}$, under section 1(4) of the United Kingdom (UK) Carriage of Goods by Sea Act 1971, as opposed to section 1(2)(a) of

\footnotetext{
${ }^{14}$ Debattista (note 7), pp. 183-187.

${ }^{15}$ The Hague-Visby rules were applicable in the judgment of the Court of Appeal of England and Wales of 17 April 2018, AP Moller Maersk A/S trading as Maersk Line v Kyokuyo Ltd (The Maersk Tangier) [2018] EWCA Civ. 778, even if a B/L "was drafted (but not issued) to cover the shipment" and a sea waybill was issued instead, following the decision of the High Court of Justice of England and Wales (Queen's Bench Division) of 14 April 1954, Pyrene Co Ltd v Scindia Steam Navigation Co Ltd [1954] 2 QB 402; M. GolDBY, “The impact of new commercial practices on liner contracts of carriage: new wine in old skins?", in Research Handbook on Maritime Law and Regulation. Edward Elgar Publishing, 2019, pp. 241-242.

${ }^{16}$ Rodríguez Delgado (note 10), p. 205.

${ }^{17}$ Debattista (note 7), pp. 183-187.

${ }^{18}$ Ibid., pp. 183-187.

${ }^{19}$ Ibid., pp. 183-187.

${ }^{20}$ English courts have held decisions on deciding the nature of the B/L; in the judgment of the Commercial Court (Queen's Bench Division of the High Court of Justice) of 14 March 2000, International Air and Sea Cargo GmbH v Chitral (Owners) (The Chitral) [2000] 1 Lloyd's Rep. 529, consignees were named but the B/L allowed for naming a 'notify party' and in its absence, the $\mathrm{B} / \mathrm{L}$ was treated as a non-negotiable sea waybill, and thus, no $\mathrm{B} / \mathrm{L}$ was required to be produced by the carrier to deliver the goods to the consignee, the original consignor bearing the right to sue based on that document; vid. Č. PEJović, "Legal issues arising from delivery of goods without a bill of lading: case study of some Asian jurisdictions", Poredbeno pomorsko pravo, Vol. 45, No. 160, 2006, pp. 1-20, at p. 15; S. BAUGHen, Shipping Law, Informa Law from Routledge, 2019, p. 45; D. SteEL J. considered that this was a matter of construction considering the B/L "as a whole"; the same tribunal on its judgment of 17 May 2002, Parsons Corp v C.V Scheepvaartonderneming (The Happy Ranger); [2002] EWCA Civ 694; [2002] 2 Lloyd's Rep. 357, where in fact no B/L was issued, the court held that the B/L was an 'order' and not a 'straight' B/L; R. AIKENS, R. LORD, M. Bools, Bills of Lading, 2nd Edition, Informa Law from Routledge, 2015, at [2.40]; small changes in the draft of the $\mathrm{B} / \mathrm{L}$ may have relevant consequences, as in the Chitral case, and unless words such as non-negotiable or non-transferable are included in the $\mathrm{B} / \mathrm{L}$ or 'to order' in the box where the consignee is named, the $\mathrm{B} / \mathrm{L}$ will be a straight $\mathrm{B} / \mathrm{L}$ even if "the small print above the signature may stipulate for delivery to the named person 'or assigns"'; J. COOKE, T. YOUNG, J. KIMBALL, L. LAMBERT, A. TAYLOR, and D. MARTOWSKI, Voyage Charters, 4th Edition, Informa Law from Routledge, 2014, at [18.143]; see AIKENS et al. (supra), at [11.14].

${ }^{21}$ Judgment of the House of Lords of 16 February 2005, J. I. Macwilliam Co Inc v Mediterranean Shipping Co SA (The Rafaela S) [2005] UKHL 11; [2005] 1 Lloyd's Rep. 347

22 BAUGHen (note 20), p. 98.
} 
the UK Carriage of Goods by Sea Act $1992 .{ }^{23}$ Section 4 of COGSA 1992 is not applicable to them..$^{24}$ The straight $\mathrm{B} / \mathrm{L}$ embodies "constructive possession of the goods" and under common law, it is considered a document of title regarding the identification of the consignee to whom the goods are delivered that needs to be known by the carrier but not regarding the delivery of goods. ${ }^{25}$

8. Under Spanish law, Article 248(1)(2) SAMN requires the $\mathrm{B} / \mathrm{L}$ to mention 'the name and surname or company name and the address or main establishment of the consignor and, if the bill is nominative (a straight $\mathrm{B} / \mathrm{L}$ ), those of the consignee', 'at the moment of delivery to the consignor'. Nominative $\mathrm{B} / \mathrm{Ls}$ are transmitted 'by assignment according to the rules governing assignment of non-endorsable credits' (Article $250 \mathrm{SAMN}$ ). These are found in the Spanish Code of Commerce, requiring the mere assignment 'by the creditor without the need for consent by the debtor, for which it shall suffice to notify him of the transfer'; moreover, the debtor is 'bound to the new creditor by virtue of the notification' (Article 347). The latter requirement, notification to discharge the cargo to the consignee is not set out in the Hague Rules but constitutes a requirement under Spanish law. ${ }^{26}$ Moreover, the assignor is not liable for the solvency of the debtor but only for the legitimacy of the credit (Article 348). ${ }^{27}$ Finally, ship's delivery orders are similar to sea waybills or straight $\mathrm{B} / \mathrm{Ls}$ but apply to the carriage of bulk cargo delivered to two or more buyers. ${ }^{28}$

9. The $\mathrm{B} / \mathrm{L}$ usually contains the general terms at the end, including the dispute resolution clause. The effectiveness of the conveyance of the $\mathrm{B} / \mathrm{L}$ and the jurisdiction clause included therein under Spanish law is the topic analysed in the judgment of the Commercial Court of Barcelona No 15 of 29 May 2020. As it has been explained, the first issue to consider in this case derives from the nature of the $\mathrm{B} / \mathrm{L}$, that unlike the non-negotiable transport documents such as the sea waybill, conveys its effectiveness (and thus, the title to the goods) to a third party. It stands as a proof of the existence of the contract but it has translational effectiveness of the property of the goods, unlike the sea waybill. The latter normally indicates the place of origin and the recipient if this party needs to pay the seller, who may also be their shipper, for the goods.

10. Since the concept has been explained of the title to the goods that the $\mathrm{B} / \mathrm{L}$ represents in the hands of the consignee, the judgment of the Provincial Court of Barcelona leads to the next question: does the conveyance of the $\mathrm{B} / \mathrm{L}$, including its jurisdiction clause, to the consignee comply with EU law? The next sections provide the facts of the case, the decision of the court of first instance, the grounds of the decision and some concluding remarks.

\section{Facts}

11. The shipper and consignor of the goods (Empacreci, SA), delivered the cargo from Guayaquil (Ecuador) to the consignee and receiver of the cargo (Congemasa, SL), in Valladolid (Spain). The claimant, Zurich Insurance PLC (the insurer), sued the defendant, CMA CGM Ibérica SAU (CMA), claiming $€ 96,656.38$ for compensation to be paid to the insured party, Congemasa, for damage suffered during the carriage of goods by sea.

\footnotetext{
${ }^{23}$ Ibid., p. 98.

${ }^{24}$ Aikens et al., (note 20), at [2.68].

${ }^{25}$ FoxTON et al. (note 1), at [5-007]; AIKENS points out that two requirements have to be met to consider the straight B/L as a document of title under common law: it is not enough for a document "produced to obtain delivery" to be considered a document of title; and even if the straight $\mathrm{B} / \mathrm{L}$ is transferred once to the consignee it does not transfer "symbolic possession" by endorsement, and is not just title, unlike a document of title; Aikens et al., (note 20), at [6.11].

${ }^{26}$ F. SÁnchez Calero, El contrato de transporte maritimo de mercancias, CSIC, 1957, p. 26; however, the judgment of the Spanish Supreme Court of 3 March 1997, ES:TS:1997:1494, considered, after analysing the American doctrine and case law, that 'straight' B/Ls and sea waybills, unlike the B/Ls 'to order' or 'to bearer' do not require the consignee to surrender the originals to the carrier at the port of discharge (ground 1); the court equals 'straight' B/Ls and 'sea waybills', contrarily to the opinion of Rodríguez Delgado (note 10), p. 200.

${ }^{27}$ Rodríguez Delgado (note 10), p. 200.

${ }^{28}$ Debattista (note 7), pp. 183-187.
} 
12. We assume that the $\mathrm{B} / \mathrm{L}$ (no. GQL0153353) was made 'to order' and endorsed to Congemasa since there is no other indication in the case. The $\mathrm{B} / \mathrm{L}$ contained an exclusive jurisdiction clause in favour of the Commercial Court of Marseille (France) in relation to any claim arising out of that document. CMA opposed the jurisdiction of the Commercial Court No 4 of Barcelona by resorting to the dispute resolution clause included in the B/L. The tribunal, in its Order of 4 June 2019, declined jurisdiction in favour of the French courts of Marseille following the choice of court agreement included in the B/L. ${ }^{29}$

\section{Grounds for appeal}

13. The defendant, CMA, argued that the Commercial Court of Marseille had jurisdiction to hear the case. The Commercial Court of Barcelona upheld this view and declined jurisdiction in the first instance based on the choice of court agreement found in the $\mathrm{B} / \mathrm{L} .{ }^{30}$ The appellant (and claimant in the first instance), Zurich, alleges that the Commercial Courts of Barcelona have jurisdiction to hear the case. The provided reasons are the following: ${ }^{31}$

1) Considerations on the privity of contract. $B / L$ clauses were negotiated between the shipper of the goods, Empacreci, and the carrier. However, the consignee, Congemasa, did not intervene in the negotiation and the $\mathrm{B} / \mathrm{L}$ clauses cannot be unilaterally imposed on third parties. Zurich, the insurer, subrogated ${ }^{32}$ in the rights of Congemasa, is not bound by such terms. The amounts claimed by CMA for the cargo damage cannot be heard by the Commercial Court of Marseille. The B/L, and thus the jurisdiction clause, is only enforceable against the contractual counterparts and is not opposable to third parties.

2) The Commercial Court of Marseille has no relationship with the contract of affreightment nor with the parties, since the defendant, Congemasa, is domiciled in Barcelona.

3) The Provincial Court of Barcelona follows its own doctrine set out by the Order rendered on 21 December 2016, in a similar case containing a choice of court agreement in favour of the courts of Marseille. The court declared null and void the clauses not negotiated according to Article 468 SAMN.

14. The defendant, CMA, argued that the parties in dispute are international companies, that there was no abuse during the contract negotiations and that Zurich's insured signed the B/L without raising any complaint before signing it. Moreover, CMA objected to the Provincial Court of Barcelona's doctrine stressing that unenforceability of choice of court agreements only refers to third parties to the contract and not to insurance companies subrogated into the rights of their policyholders. ${ }^{33}$

\section{Grounds of the decision}

15. The Provincial Court of Barcelona backs its arguments regarding the enforceability of jurisdiction clauses inserted into a B/L by relying on the doctrine set out in its Order of 21 December $2016,{ }^{34}$

\footnotetext{
${ }^{29}$ Judgment of the Provincial Court of Barcelona of 29 May 2020, para. 1.

${ }^{30}$ Ibid., para. 2-3.

${ }^{31}$ Ibid., para. 4.

${ }^{32}$ When Spanish law applies, the insurer subrogates in the rights and obligations of the insured under the conditions and limitations set out by Article 437(5) SAMN, with similar provisions to the insurance on cargo carried by land prescribed by Article 43 of the Spanish Act, 50/1980 of 8 October 1980, on Insurance Contracts (Official Journal No. 250 of 17 October 1980); T. Fernández-Quirós Tuñón, J. López Quiroga, and A. Cabellos Ballenilla (eds.), Guía sobre la Ley 14/2014, de 24 de julio, de Navegación Marítima, Uría Menéndez, 2014, p. 68.

${ }^{33}$ Judgment of the Provincial Court of Barcelona of 29 May 2020, para 5.

${ }^{34}$ ECLI: ES: APB: 2016: 5241A.
} 
reiterated in the judgment of 23 July $2019,{ }^{35}$ among others. The court stresses that the doctrine, in line with that of the Spanish Supreme Court, had to be reviewed after the entry into force of the SAMN. ${ }^{36}$

16. As Fernández Rozas points out, ${ }^{37}$ the unification of the Spanish laws on jurisdiction has 'facilitated a generalised recognition of the choice of court agreements' ${ }^{38}$ fostering not just their predictability and effectiveness in international transactions but also their admission by courts against any obstacles posed by national regulations. This is evidenced by the protective rules enshrined in Article 22 of the Spanish Law on the Judiciary (SOLJ).$^{39}$ According to the CJEU in the Benincasa case: ${ }^{40}$

"A jurisdiction clause, which serves a procedural purpose, is governed by the provisions of the Convention, whose aim is to establish uniform rules of international jurisdiction. In contrast, the substantive provisions of the main contract in which that clause is incorporated, and likewise any dispute as to the validity of that contract, are governed by the lex causae determined by the private international law of the State of the court having jurisdiction".

17. That Article sets out the scope of the Spanish court's powers to assume exclusive jurisdiction, general jurisdiction in the absence of the parties' choice of court agreement and, finally, jurisdiction based on the choice of forum. The latter can be submitted to foreign courts when public order and sovereignty are not compromised, following the Spanish Supreme Court's doctrine on the interpretation of the Spanish procedural rules. ${ }^{41}$ Moreover, 'Spanish civil courts shall refrain from dealing with any matters brought before them where any of the following circumstances may exist [...] where a matter is exclusively attributed to another state's jurisdiction by virtue of an international treaty or convention to which Spain is a party', according to Article 36(2)(b) of the Spanish Law on Civil Procedure (SLCP). ${ }^{42}$

\section{Party autonomy in contracts for the carriage of goods by sea}

18. The principle of party autonomy, according to the judging tribunal and the Spanish Supreme Court's doctrine, is enshrined in Article 1255 of the Spanish Civil Code, ${ }^{43}$ Article 21 of the SOLJ, as well as Article 25 of the Brussels I Regulation (recast). ${ }^{44}$ The first Article provides that 'the contracting par-

\footnotetext{
${ }^{35}$ ECLI: ES: APB: 2019: 9715.

${ }^{36}$ Judgment of the Provincial Court of Barcelona of 29 May 2020, para. 6.

${ }^{37}$ J. C. FERnÁNDEZ RozAs, "Alternativas e incertidumbres de las cláusulas de solución de controversias en la contratación marítima internacional = Alternatives and uncertainties of the dispute settlement clauses in international maritime contracts", CDT, Vol. 10, No. 2, 2018, p. 351.

${ }^{38}$ See A. Rodríguez Benot, "Delimitación de la noción de consumidor en la contratación mercantil internacional a los fines de la determinación del órgano judicial competente según el Convenio de Bruselas de 1968 (Comentario a la sentencia del Tribunal de Justicia de las Comunidades Europeas en el asunto C-269/95, 'Francesco Benincasa c. Dentalkit SRL', de 3 julio 1997)", Revista Jurídica Española La Ley, No. 6, 1997, pp. 1651-1660; the same autor comments on the Benincasa judgment in "Jurisprudencia Española y Comunitaria de Derecho Internacional Privado", REDI, Vol. 50, No. 1, 1998, pp. 277-342, at pp. 292-297; as cited by FERNÁNDEZ Rozas (note 37), p. 351.

${ }^{39}$ Law 6/1985 of 1 July 1985 on the Judiciary (['Ley Orgánica del Poder Judicial' (LOPJ)] published in the Official State Gazette no 157 of 2 July 1985, as amended up to Law No 16/2015 of 27 October 2015.

${ }^{40}$ Judgment of the CJEU of 3 July 1997, Francesco Benincasa v Dentalkit Srl., C-269/95, EU:C:1997:337, para. 25.

${ }^{41}$ Judgment of the Provincial Court of Barcelona of 29 May 2020, para. 7.

${ }^{42}$ Spanish Law 1/2000 of 7 January on Civil Procedure ([SLCP] 'Ley de Enjuiciamiento Civil' [LEC] in Spanish) published in the Official State Gazette No 7 of 8 January 2000 and amended by Spanish Law 42/2015 of 5 October; judgment of the Provincial Court of Barcelona of 29 May 2020, para. 8.

${ }^{43}$ Spanish Civil Code, approved by Royal Decree of 24 July 1889 (Official State Gazette No 206 of 25 July 1889).

${ }^{44}$ Article 25 of Regulation (EU) No 1215/2012 of the European Parliament and of the Council of 12 December 2012 on jurisdiction and the recognition and enforcement of judgments in civil and commercial matters [2012] OJ 2012, L351/1 (Brussels I Regulation (recast); vid. Article 23 of Council Regulation (EC) 44/2001 of 22 December 2000 on jurisdiction and the recognition and enforcement of judgments in civil and commercial matters [2001] OJ 2001, L 012/1 (Brussels I Regulation), and Article 17 of the Convention of 27 September 1968 on jurisdiction and the enforcement of judgments in civil and commercial matters OJ 1972, L 299/32, consolidated text of 26 January 1998 [1998] OJ 1998 C 27/1 (Brussels Convention).
} 
ties may establish any covenants, clauses and conditions deemed convenient, provided that they are not contrary to the laws, to morals or to public order'. The second Article provides in its first paragraph that 'Spanish courts will hear claims arising in the Spanish territory', subject to international conventions ratified by Spain, as well as EU regulations and Spanish laws. This is reinforced by the fact that Article 4 bis (1) SOLJ compels the Spanish judges to apply EU law in accordance with the CJEU's jurisprudence.

19. First, the transaction to where the choice of court agreement points giving rise to the dispute must fall within the scope of application of the Brussels I Regulation (recast): (a) material, i.e. civil and commercial under Article 1(1), with the exclusion under Article 1(2) of status and capacity, maintenance obligations, social security obligations, wills and succession, arbitration, bankruptcy and insolvency proceedings, rights in property arising out of a matrimonial or analogous relationship; (b) temporal, since 1 January 2015; (c) personal, regardless of the domicile or nationality of the parties although national law applies to non-EU domiciled defendants and the Regulation to EU domiciled defendants, with the exceptions available under Articles 17(2), 24 or 25 of the Regulation; (d) and geographical, i.e. in all the EU territory. ${ }^{45}$

20. Second, Article 25 (exclusive jurisdiction agreements) of the Brussels I Regulation (recast) prevails over the general rule of Article 4 (domicile of the defendant), but both are displaced by Article 26 (tacit agreement) of the Regulation. The conditions for the formal validity and the consent of the parties in case of submission agreements to EU Member State courts are included in Article 25. None of the parties is required to be domiciled in an EU Member State. However, the provision does not contain the requirements for the substantive validity of the choice of forum clauses that are 'subject to the law of the EU Member State court where enforcement is sought'. ${ }^{46}$

21. Any agreement conferring jurisdiction on the courts of an EU Member State is ineffective unless it fulfils one or more of the following conditions set out in Article 25(1) of the Regulation: (a) 'in writing or evidenced in writing'; (b) in a form which accords with practices which the parties have established between themselves'; ${ }^{47}$ or (c) in international trade or commerce, in a form which accords with a usage of which the parties are or ought to have been aware and which in such trade or commerce is widely known to, and regularly observed by, parties to contracts of the type involved in the particular trade or commerce concerned' (in the present case of the Provincial Court of Barcelona of 29 May 2020, in shipping trade). Regarding the latter condition, the CJEU has rendered several preliminary rulings. ${ }^{48}$

\footnotetext{
${ }^{45}$ P. FranZINA, "The recasting of Brussels I Regulation - Scope of application and Jurisdiction in civil and commercial

Matters", EJTN Civil Justice seminar, Brussels I regulation - jurisdiction and the recognition and enforcement of judgements in civil matters, Zagreb, 16 May 2018.

${ }^{46} \mathrm{~J}$. EcheBARRIA FernÁNDEZ, "Limitations on jurisdiction and arbitration agreements based on applicable law and the identity of the carrier in cargo claim disputes: who and where to sue? = Las limitaciones a la autonomía la voluntad de las partes en las cláusulas atributivas de jurisdicción y las cláusulas de arbitraje basadas en la ley aplicable y la identidad del transportista en las reclamaciones por pérdida o daños a las mercancías: ¿a quién y dónde se puede reclamar?”, $C D T$, vol. 11, No. 1, 2019, pp. 306-321, at p. 308 .

${ }^{47}$ Vid. the judgment of 14 October 2000 rendered by Lord Justice Aikens at the Commercial Court (Queen's Bench Division) of the High Court of England \& Wales, OT Africa Line Ltd v Hijazy (The Kribi) [2001] 1 Lloyd's Rep. 76.

${ }^{48}$ See the judgments of the CJEU of: 14 December 1976, Estasis Salotti di Colzani Aimo e Gianmario Colzani s.n.c. v Rüwa Polstereimaschinen GmbH, C-24-76, EU:C:1976:177; 14 December 1976, Galeries Segoura SPRL v Société Rahim Bonakdarian, C-25-76, EU:C:1976:178; and 14 December 1977, Theodorus Engelbertus Sanders v Ronald van der Putte, C-73-77, EU:C:1977:208.
} 


\section{Validity of the parties' consent to be bound by a jurisdiction agreement included in a $B / L$}

22. The Provincial Court of Barcelona refers to its Order of 18 March $2009,{ }^{49}$ regarding the requirements for the valid consent by the parties to a choice of court agreement: $:^{50}$

a) The court refers to the Transporti Castelletti case ${ }^{51}$ to assess the parties' consent to a jurisdiction clause; it needs to be consistent with the "practice in force in the area of international trade or commerce in which the parties in question are operating and the parties are or ought to have been aware of that practice", 52 moreover, "in international trade or commerce, a jurisdiction clause may be validly concluded in a form which accords with practices in that trade or commerce of which the parties are or ought to have been, aware", ${ }_{53}$ as prescribed by the third novel hypothesis to the second sentence of the first paragraph of Article 17, introduced by the Accession Convention of Denmark, Ireland, and the United Kingdom of 9 October 1978; ${ }^{54}$ finally, it must be "assessed solely in the light of the commercial usages of the branch of international trade or commerce concerned, without taking into account any particular requirements which national provisions might lay down", 55

b) "There is a practice in the branch of trade or commerce in question in particular where a particular course of conduct is generally and regularly followed by operators in that branch when concluding contracts of a particular type"; 56

c) "Knowledge of the practice must be appreciated in relation to the original parties to the jurisdiction agreement, regardless of their nationality in this regard";

d) Finally, the Provincial Court of Barcelona refers to dilatory practices, such as the "Italian torpedo 'actions, ${ }^{57}$ aimed at filing claims in courts other than those designated by the parties to challenge the validity of the choice of court agreements included in B/Ls. That practice, followed by numerous shippers endorsing B/Ls, "does not modify their validity while their incorporation continues being accredited and corresponds to a general and regular practice".

23. The most important requirement set out in the Trasporti Castelletti case, self-explanatory, is that the commercial usages generally followed by the shipping industry must be followed, without resorting to any national law requirements. It is usual practice that a jurisdiction clause contained in or incorporated into a $\mathrm{B} / \mathrm{L}$ can be invoked against the third party $\mathrm{B} / \mathrm{L}$ holder since the latter is surrogated

\footnotetext{
${ }^{49}$ Judgment of the Provincial Court of Barcelona No. 15 of 18 March 2009, ES: APB 2009 / 4315A.

${ }^{50}$ Judgment of the Provincial Court of Barcelona of 29 May 2020, para. 10.

${ }^{51}$ Judgment of the CJEU of 16 March 1999, Trasporti Castelletti Spedizioni Internazionali SpA v Hugo Trumpy SpA, C-159/97, EU:C:1999:142.

${ }^{52}$ Judgment of the CJEU of 20 February 1997, MSG v Les Gravières Rhénanes SARL, C-106/95 EU:C:1997:70, para. 20.

${ }^{53}$ Les Gravières Rhénanes, para. 16; Castelletti, para. 18.

${ }^{54}$ Council Convention, signed at Luxembourg on 9 October 1978, on the accession of the Kingdom of Denmark, of the Republic of Ireland and of the United Kingdom of Great Britain and Northern Ireland to the Convention on Jurisdiction and the Enforcement of Judgments in Civil and Commercial Matters, and to the Protocol on its interpretation by the Court of Justice, 78/884/EEC, 1978, OJ L 304/1.

${ }^{55}$ Castelletti, para. 39.

${ }^{56}$ Les Gravières Rhénanes, para. 23.

${ }^{57}$ The 'Italian torpedo actions' can be characterised as negative but positive declaratory judgments, as stated by J. CARRASCOSA GONZÁLEZ in a written communication provided to this author on 26 November 2020; furthermore, the 'Italian torpedo actions' follow the 'prior in tempore potior in iure' principle, and are no longer available under the Brussels I Regulation (recast) regime, requiring that the EU Member State court chosen by the parties assesses its jurisdiction to hear the case under Article 31(2) while the court first seised stays the proceedings according to Article 29 (1). Furthermore, Article 29(2) states that 'any other court seised shall without delay inform the former court of the date when it was seised in accordance with Article 32'; J. ECHEBARRIA FERNÁNDEZ, Jurisdiction and arbitration agreements in contracts for the carriage of goods by sea - limitations on party autonomy, Informa Law from Routledge, 2021, p. 29; the doctrine has widely analysed the 'Italian torpedo actions', vid. J. Suderow, "Cuestiones de jurisdicción internacional en torno a la aplicación privada del Derecho antitrust: forum shopping y demandas torpedo, CDT, Vol. 2, No. 2, 2010, pp. 315-331; and P. Blanco-Morales Limones, "Acciones declarativas negativas y forum delicti commissi. ¿Galgos o podencos?: la litispendencia. Comentario a la Sentencia del Tribunal de Justicia (Sala Primera) de 25 de octubre de 2012. Folien Fischer AG y Fofitec AG contra Ritrama SpA", CDT, Vol. 5, No. 1, 2013, pp. $240-253$.
} 
into the rights and obligations of the shipper. ${ }^{58}$ The requirements regarding the formal and substantive validity of that agreement of Article 25(1) of the Brussels I Regulation (recast) must be observed.

\section{Effectiveness of the conveyance of B/L clauses to third parties under the CJEU's doctrine}

24. Some scholars have expressed that the main problem in the shipping sector derives from the fact that unlike the carrier, "certain agents involved in the carriage of goods by sea under the B/L regime, the shipper and the receiver of the goods in particular", are unaware of the jurisdiction and applicable law according to that document. ${ }^{59}$ It is widely understood by the doctrine that the "mere printing of a clause on the back of a B/L is not generally enough" to incorporate the choice of court agreement. ${ }^{60}$ The shipper must assent in writing or comply with any of the conditions set out in Article 25(1) the Brussels I Regulation (recast) ${ }^{61}$ As stated by the CJEU in the Tilly Russ ${ }^{62}$ and Trasporti Castelletti judgments, the proper assent by the shipper binds the endorsee. English courts, bearing a long tradition in shipping and cargo claim disputes, follow this approach when applying the Brussels I Regulation (recast).$^{63}$ The Provincial Court of Barcelona correctly relies on the doctrine set out by the Coreck Maritime case ${ }^{64}$ in this respect by stating that when: ${ }^{65}$

"a party not privy to the original contract against whom a jurisdiction clause is relied on has succeeded to the rights and obligations of one of the original parties [...] according to the applicable national law, [...] there is no need to ascertain whether he accepted the jurisdiction clause in the original contract”.

25. The third party $\mathrm{B} / \mathrm{L}$ holder acquires no more than the rights and obligations vested in the original parties and is subject to all the obligations included in the $\mathrm{B} / \mathrm{L}$, including the choice of court agreement. Regarding the enforceability of a jurisdiction clause, included in a B/L and agreed between a carrier and a shipper, against a third party bearer of a $\mathrm{B} / \mathrm{L}$, the latter must have "succeeded to the rights and obligations of the shipper under the applicable national law when he acquired" it; if the answer is negative, the conditions must be ascertained according to Article 25 of the Brussels I Regulation (recast). ${ }^{66}$

26. The determination of the applicable national law to determine the rights and obligations of a third party bearer of a $\mathrm{B} / \mathrm{L}$ "falls within the jurisdiction of the national court, which must apply its rules of private international law". ${ }^{67}$ Furthermore, any "lacuna in the applicable national law, apart from being hypothetical, is not one of the interpretation of the [Brussels] Convention (currently the Brussels I Regu-

${ }^{58}$ U. BelintXon Martin, "Derecho internacional privado y Derecho marítimo internacional: competencia judicial internacional y acuerdos atributivos de jurisdicción en la LNM = Private International Law and Maritime International Law: jurisdiction and jurisdiction agreements in Law of Maritime Navigation”, CDT, No. Vol. 12, No. 2, 2020, pp. 112--135, at p. 129.

${ }^{59}$ V. Fuentes CAmacho and R. SAnZ Abascal, “¿Puede afectar una cláusula de sumisión expresa incluida en un conocimiento de embarque a una aseguradora que alega no haberla suscrito? (algunas reflexiones en torno a la Sent. TS (Sala $1^{\text {a }}$ ) de 29 septiembre 2005)", La Ley, No. 6390, 2005, pp. 2-3; in FERnÁNDEZ RozAS (note 37), p. 357.

${ }^{60}$ Foxton et al. (note 1), at [21-006].

${ }^{61}$ Judgment of the CJEU of 19 June 1984, Partenreederei ms. Tilly Russ and Ernest Russ $v$ NV Haven- \& Vervoerbedrijf Nova and NV Goeminne Hout, C-71/83, ECLI:EU:C:1984:217; see also the judgment of 14 October 2000 of the Commercial Court (Queen's Bench Division) of the High Court of England \& Wales, OT Africa Line Ltd v Hijazy (The Kribi) [2001] 1 Lloyd's Rep. 76.

${ }^{62}$ Judgment of the CJEU 19 June 1984, Partenreederei ms. Tilly Russ and Ernest Russ $v$ NV Haven- \& Vervoerbedrijf Nova and NV Goeminne Hout, C-71/83, EU:C:1984:217.

${ }^{63}$ Undisclosed principals concerning a bareboat charterparty and a CIF buyer in relation to a B/L to were bound by exclusive jurisdiction agreements in: Kaefer Aislamientos SA de CV v AMS Drilling Mexico (The Atlantic Tiburon 1) [2019] EWCA Civ 10; [2019] 2 Lloyd's Rep. 128; and Pan Ocean Co Ltd v China-Base Group (The Grand Ace 12) [2019] EWHC 982 (Comm); [2019] 1 Lloyd's Rep. Plus 76, respectively; D. FoxTon et al. (note 1), at [21-006].

${ }^{64}$ Judgment of the CJEU of 9 November 2000, Coreck Maritime GmbH v Handelsveem BV and Others, Case C-387/98, EU:C:2000:606.

${ }^{65}$ Coreck Maritime, para. 25; Tilly Russ, para. 25; Trasporti Castelletti, para. 41.

${ }^{66}$ Coreck Maritime, para. 27; the judgment refers to Article 17 of the Brussels Convention, currently Article 25 of the Brussels I Regulation (recast).

${ }^{67}$ Coreck Maritime, para. 30. 
lation (recast))". ${ }^{68}$ This intricate system relies on the Brussels I Regulation (recast)'s Recital 20 that states the following: "where a question arises as to whether a choice-of-court agreement in favour of a court or the courts of a Member State is null and void as to its substantive validity, that question should be decided in accordance with the law of the Member State of the court or courts designated in the agreement, including the conflict-of-laws rules of that Member State'. The Recital is consistent with the first sentence of Article 25(1) of the Brussels I Regulation (recast) that clarifies the following: 'if the parties, regardless of their domicile, have agreed that a court or the courts of a Member State are to have jurisdiction to settle any disputes which have arisen or which may arise in connection with a particular legal relationship, that court or those courts shall have jurisdiction, unless the agreement is null and void as to its substantive validity under the law of that Member State. Such jurisdiction shall be exclusive unless the parties have agreed otherwise'. The substantive validity of the choice of court agreement must be assessed in the light of the law of the chosen courts, being the courts of Marseille in the present case.

\section{Divergence from the CJEU's doctrine regarding the rights and obligations of the third party endorsee to the $B / L$ containing a jurisdiction agreement negotiated between the shipper and the carrier}

27. The Provincial Court of Barcelona reiterates the validity of the doctrine set out in its Order of 21 December 2016. The tribunal, following the Advocate General (A. G.) Alber's Opinion ${ }^{69}$ in the Coreck Maritime case, dares to step not just into interpreting the CJEU's preliminary ruling but also amending it. Accordingly, the national court decides which national law applies "to determine whether the third-party holder of a bill of lading has succeeded to the shipper's rights and obligations"; the same principle applies when this is not regulated under national law. ${ }^{70}$

28. The Spanish court, contrarily, reiterates that it has previously accepted that these clauses are binding on third party B/L holders in its Orders of 18 March $2009^{71}$ and 11 March $2010^{72}$ in accordance with the current Article 25 of the Brussels I Regulation (recast), ${ }^{73}$ following the Spanish Supreme Court's judgment of 29 September $2005 .^{74}$ The latter correctly applies the doctrine set out by the CJEU in the Trasporti Castelletti case. Furthermore, the judgment of the Provincial Court of Barcelona of 13 February $2019^{75}$ declares that dilatory tactics such as filing claims at courts other than the one designated under the forum agreement does not make customs and usages followed in the shipping sector to decay. ${ }^{76}$ The validity of such jurisdiction clauses is not privy to the carrier and the shipper who signed the $\mathrm{B} / \mathrm{L}$ and extends to a third party endorsee such as the insurance company subrogated in its insured's

\footnotetext{
${ }^{68}$ Coreck Maritime, para. 31; F. J. Garcimartín Alférez, "Prorogation of Jurisdiction - Choice of Court Agreements and Submission (Arts. 25-26)", in A. Dickinson, E. LeIN, and A. JAmES (eds.), The Brussels I Regulation Recast, Oxford University Press, 2015, pp. 25-26.

${ }^{69}$ Opinion of Advocate General (A. G.) Alber delivered on 23 March 2000, Coreck Maritime GmbH v Handelsveem BV and Others, C-387/98, EU:C:2000:157.

${ }^{70}$ A. G. Alber's conclusions at para. 4; the judgment of the Provincial Court of Barcelona of 21 December 2016 reaches the same conclusions; judgment of the Provincial Court of Barcelona of 29 May 2020, para. 13.

${ }^{71}$ ES:APB 2009/4315.

72 ES:APB 2010/2627.

${ }^{73}$ Judgment of the Provincial Court of Barcelona of 29 May 2020, para. 14

${ }^{74}$ ES:TS:2005:5650; the Spanish Supreme Court reiterates its doctrine in the judgments of 8 February 2007, ES:TS:2007:452, and 16 May 2008, ES:TS:2008:2182; judgment of the Provincial Court of Barcelona of 29 May 2020, para. 15.

${ }^{75}$ ES:APB:2016:5241A; for a further analysis on the judgment, vid. J. J. ÁlvAREz RuBIO, "Una acertada orientación jurisprudencial en relación a la validez y alcance de la cláusula sumisoria a favor de tribunal extranjero contenida en un conocimiento de embarque. Comentario al Auto de 13 de febrero de 2019 de la AAP de Barcelona (Sección 15) = A correct jurisprudential orientation in relation to the validity and scope of the submission clause in favour of a foreign court contained in a bill of lading. Commentary on the Judgment of 13 February 2019 of the Provincial Court of Barcelona (Section 15)', CDT, Vol. 11, No. 2, 2019, p. 388-401, at p. 396.

${ }^{76}$ Judgment of the Provincial Court of Barcelona of 13 February 2019, para. 3.
} 
position (judgment of the Spanish Supreme Court of 8 February 2007). ${ }^{77}$ The third party must succeed the shipper in his rights and obligations in accordance with the national applicable law to the contract as already mentioned regarding the Coreck Maritime case. ${ }^{78}$ However, the Provincial Court of Barcelona acknowledges that the SAMN has modified the previous legal regime. ${ }^{79}$

29. points out that Spanish judges will apply EU law following the CJEU's jurisprudence according to Article 4 bis (1) SOLJ, and Article 21(1) SOLJ sets out that the 'Spanish civil courts will hear claims that arise within Spanish territory in accordance with the stipulations of the international conventions and treaties to which Spain is a party, the regulations of the European Union and Spanish laws'. The SAMN has translated this statement in its Article 2(1), under which the Act is applicable when it does not contravene the provisions of EU law regulating the same matters.

30. Article 469 SAMN establishes the criteria conferring jurisdiction in the absence of a valid jurisdiction or arbitration agreement in favour of Spanish tribunals. Article 468 SAMN ('Jurisdiction and arbitration clauses') requires the individual and separate negotiation of dispute resolution clauses ${ }^{80}$ while Article 251 SAMN ('Effectiveness of conveyance') $)^{81}$ prescribes that consent must be given by the acquirer of the goods. As stated by some scholars, national legislative changes do not contravene the requirements for the validity of a jurisdiction or arbitration agreement subject to an international treaty. ${ }^{82}$ Moreover, Articles 22 bis (2) SOLJ and 468 SAMN include rules applicable in the absence of a choice of forum that lie within the scope of Article 25 of the Brussels I Regulation (recast). ${ }^{83}$ According to the Preamble (section XI) of the Act, a reform is sought:

'On the basis of the rules of Act 1/2000, dated 7th January, on Civil Procedure, Title IX of the Act concerns the 'procedural specialities.'

Chapter I contains what are known as specialities of jurisdiction and power that, based on the preferential application in this matter of the rules contained in the international conventions and in the provisions of the European Union, aims to avoid abuse detected, declaring the nullity of clauses of submission to a foreign jurisdiction or arbitration abroad, contained in ship use contracts or in ancillary navigation contracts, when these have not been negotiated individually and separately'.

31. 'Prorogatio fori' is the positive effect as a result of a choice of an EU Member State court by the parties, regardless of their domicile, in a charterparty or a B/L, ${ }^{84}$ and the separability of this agre-

\footnotetext{
${ }^{77}$ As stated in the second ground of the judgment of the Spanish Supreme Court of 8 February 2007, ES:TS:2007:452FD; ANTÓN JUÁREZ (note 2), pp. 232-235.

${ }^{78}$ Coreck Maritime, paras. 23 and 24.

${ }^{79}$ Judgment of the Provincial Court of Barcelona of 29 May 2020, para.16.

${ }^{80}$ According to that provision:

'Without prejudice to the terms foreseen in the international conventions in force in Spain and the provisions of the European Union, clauses of submission to a foreign jurisdiction or arbitration abroad shall be null and void and considered not to be included, as set forth in contracts for use of the ship, or in ancillary navigation contracts, when they have not been negotiated individually and separately.

In particular, insertion of a jurisdiction or arbitration clause in the printed conditions of any of the contracts referred to in the preceding paragraph shall not provide evidence, in itself, of fulfilment of the requisites established therein'.

${ }^{81}$ Article 251 SAMN provides the following:

'Conveyance of the bill of lading shall take the same effects as delivery of the goods represented, without prejudice to the relevant criminal and civil actions to which the party illegitimately dispossessed of such may be entitled. The acquirer of the bill of lading shall acquire all the rights and actions of the conveyor to the goods, with the exception of agreements regarding jurisdiction and arbitration, which shall require the consent of the acquirer pursuant to the terms stated in Chapter I of Title IX'.

${ }^{82}$ A. BAdia, "Jurisdicción y competencia", in J. C. Fuentes Gómez et al. (eds.), Comentarios a la Ley de Navegación Marítima, Dykinson, 2015, pp. 417 et seq., at p. 426; N. IRÁCULIS ARREGUI, "La controvertida negociación individual y separada de las cláusulas de jurisdicción y arbitraje en la Ley de Navegación Marítima", Revista de derecho del transporte: Terrestre, marítimo, aéreo y multimodal, No. 19, 2017, pp. 173-208; in ECHEBARRIA FERNÁNDEZ (note 57), pp. 75-76.

${ }^{83}$ See F. Garau Sobrino, "Los acuerdos atributivos de jurisdicción en Derecho Procesal Civil Internacional Español”, CDT, Vol. 2, No. 2, 2010, 52-91; J. J. Álvarez Rubio (note 75), at p. 396; in Echebarria Fernández (note 57), pp. 75-76.

${ }^{84}$ P. A. De Miguel Asensio, "El nuevo reglamento sobre competencia judicial y reconocimiento y ejecución de resolu-
} 
ement makes it enforceable even if the contract is declared null or invalid according to Article 25(5) of the Brussels I Regulation (recast). ${ }^{85}$

32. The Provincial Court of Barcelona recognises that Article 25 is applicable to the jurisdiction agreements contained in a $\mathrm{B} / \mathrm{L}$ binding the shipper and the carrier (inter partes). It points out that when an agreement is in favour of the Spanish courts, these can judge its validity in accordance with Article 468 SAMN without displacing the European legislation, neither complementing nor introducing new requirements. ${ }^{86}$ However, it does not reach the same conclusion as to whether a submission agreement binds the recipients and the successive B/L holders by relying, apparently, on the Coreck Maritime case.$^{87}$ The court points out that the effectiveness of the conveyance is contained in Article 251 SAMN, requiring the individual and separate negotiation to acquire the rights and obligations under the $B / L,{ }^{88}$ i.e., subrogation on the shipper's rights according to the applicable legislation, to be decided by the national judge, or the signature. ${ }^{89}$

33. Is this interpretation consistent with the doctrine set out by the CJEU in judgments such as Trasporti Castelletti or Coreck Maritime? Certainly not; the verification of consent is necessary if the $\mathrm{B} / \mathrm{L}$ holder does not acquire the rights and obligations of the shipper under national law. ${ }^{90}$ What national law is applicable in the judgment of 29 May 2020 of the Provincial Court of Barcelona? French law applies, following the choice of court by the parties to solve their disputes, as the first sentence of Article 25(1) of the Brussels I Regulation (recast) certainly clarifies.

\section{Applicability of the restrictive approach to the case}

34. As the Provincial Court of Barcelona announces, following its line of argument, the $\mathrm{B} / \mathrm{L}$ has been signed by Empacreci, SA (the shipper) and a carrier, to carry the goods from Guayaquil (Ecuador) to Valladolid (Spain), Congemasa being the consignee or receiver of the goods. The tribunal reiterates its doctrine, the Zurich needs to be "subrogated in the shipper's rights in accordance with applicable national law" to successfully be subject to the choice of the Commercial Court of Marseille. ${ }^{91}$

35. The Spanish Conflict of Laws or Private International Law determine the applicable law. Articles 8-12 of the Spanish Civil Code ${ }^{92}$ does not cover all cases and "its provisions have been displaced, to a large extent, by Regulation (EC) No 593/2008 of the European Parliament and of the Council of 17 June 2008 on the law applicable to contractual obligations (Rome I Regulation)". ${ }^{33}$ The Regulation excludes B/Ls from its material scope of application in the Preamble, at [9], and Article 1(2)(d), where it refers to any 'obligations arising under bills of exchange, cheques and promissory notes and other negotiable instruments to the extent that the obligations under such other negotiable instruments arise out of their negotiable character' ${ }^{94}$

\footnotetext{
ciones", Year XXXIV, No. 8013, La Ley, 2013, pp. 1-4; A. P. ABARCA JunCO, "La competencia judicial de los tribunales españoles: Foro de la autonomía de la voluntad", in A. P. ABARCA JunCo and others (eds.) Derecho Internacional Privado, UNED, 2013, p. 134; in ECHEBARRIA FERNÁNDEZ (note 57), pp. 75-76.

85 J. J. Álvarez Rubio (note 75), at p. 397; in Echebarria Fernández (note 57), pp. 75-76.

${ }^{86}$ Judgment of the Provincial Court of Barcelona of 29 May 2020, para. 18.

${ }^{87}$ Ibid., para. 19.

${ }^{88}$ Ibid., para. 20.

${ }^{89}$ Ibid., para. 21.

${ }^{90}$ ECHEBARRIA FernándeZ (note 57), pp. 71-72.

${ }^{91}$ Ibid., paras. 22-23.

${ }^{92}$ Spanish Civil Code, approved by Royal Decree of 24 July 1889 (Official State Gazette No 206 of 25 July 1889).

${ }^{93}$ The Rome I Regulation (EU Regulation 593/2008) came into force on 17 December 2009, and is applicable to all EU Member States except Denmark.

${ }^{94}$ Judgment of the Provincial Court of Barcelona of 29 May 2020, para. 24.
} 
36. The court continues its analysis in the judgment of the Provincial Court of Barcelona of 29 May 2020 and points out that Article 10(3) of the Spanish Civil Code establishes that 'the issuance of securities shall be subject to the law of the place where it takes place' and thus, conveyance of the B/L is excluded from the provision. 'Possession, ownership and other rights' over movable property 'shall be governed by the law of the place where such property is located' (Ecuadorian law). The solution offered assimilates to the place of delivery set out in Article 5(1) of the Rome I Regulation, under which 'to the extent that the law applicable to a contract for the carriage of goods has not been chosen in accordance with Article 3, the law applicable shall be the law of the country of habitual residence of the carrier, provided that the place of receipt or the place of delivery or the habitual residence of the consignor is also situated in that country'. If those conditions fail to be met, as in the case being analysed, 'the law of the country where the place of delivery as agreed by the parties is situated applies'. However, the scope of analysis is based on "the enforceability of the French jurisdiction clause rather than its validity". ${ }^{5}$

37. The court finally decides that Zurich cannot be subrogated in the position of its insured (Congemasa), since the latter was not subrogated in the rights and obligations of the shipper (Empacreci) regarding the French jurisdiction agreement that required its acceptance. The requirements of Article 251 SAMN ('consent of the acquirer' pursuant to an individual and separate negotiation) according to Article 468 SAMN are not met. ${ }^{96}$ For the previous reasons, the court declares that Congemasa did not agree to submit any disputes to the Court of Marseille and that Zurich's appeal is dismissed and the appealed resolution is declared null. ${ }^{97}$ Regrettably, it is not the first time that the Provincial Court of Barcelona No. 15 has applied a restrictive approach that hinges on a distorted interpretation of the CJEU's doctrine and, as already explained in this article, is presumably inconsistent with some of its previous decisions.

\section{Final remarks: an unsound doctrine on the prevalence of Articles 468 and 251 SAMN over Article 25 of the Brussels I Regulation (recast)}

38. Fernández Rozas and Belintxon Martin, among many scholars, criticise the Order of the Provincial Court of Barcelona of 21 December 2016 for the same reasons as those applicable to the case analysed in this commentary, refusing permission for the court to decline its jurisdiction in favour of the courts of Marseille. ${ }^{98}$ The agreement was enforceable against a third party under French law and the effectiveness of the conveyance of the B/L terms could not be subject to Article 251 SAMN. The facts are the following: DECA 1285 S.L. claimed against the carrier for the theft suffered during the carriage of 20 tons of shrimps carried from Puerto Cortés in Honduras to the port of Algeciras in Spain. The Commercial Court of Barcelona No. 10 correctly applied Article 25 of the Brussels I Regulation (recast) though neither the shipper nor the recipient had signed the $\mathrm{B} / \mathrm{L}$ and declined its jurisdiction in favour of the Commercial Court of Marseille. However, it is not a welcome development that, as previously stated, the requirements of Articles 468 and 251 SAMN regarding the conveyance of the B/L prevailed over the European rules.

39. The judgment of the Provincial Court of Barcelona of 29 May 2020, in the same manner, breaks with the customs and usages of the shipping sector, reinterpreting Article 25 of the Brussels I Regulation (recast), notably "on the governing law to verify the material validity of the agreement" submitted to an EU Member State court, France, in the case analysed in this commentary. The Provincial Court of Barcelona in its judgments of 23 July 2019,,${ }^{99} 24$ April $2020,{ }^{100}$ and 6 October $2020^{101}$ follows the same

\footnotetext{
${ }^{95}$ Ibid., para. 25.

${ }^{96}$ Ibid., para. 26.

${ }^{97}$ Ibid., para. 27.

${ }^{98}$ FERNÁNDEZ RozAs (note 37), p. 362-363.

${ }^{99}$ ES:APB:2019:9715.

${ }^{100}$ ES:APB:2020:2814A.

${ }^{101}$ ES:APB:2020:7688A.
} 
argument. Contrarily, some judgments from the Provincial Court of Barcelona No. 15 itself, such as the Order of 13 February 2019, ${ }^{102}$ and other Spanish courts ${ }^{103}$ have followed the Spanish Supreme Court's doctrine in relation to commercial customs and usages and the respect owed to the application of international treaties ratified by Spain as well as to the application of EU law. ${ }^{104}$ Article 25 of the Brussels I Regulation (recast) prevails over the SAMN and remains as the applicable rule to determine the validity of a choice of court agreement. Article 468 SAMN applies to extra-EU Member State court agreements and "private international arbitration agreements that do not fall within the scope of application of any international convention signed by Spain". ${ }^{105}$ It can be argued that the recognition and enforcement of arbitral agreements is not subject to a restrictive approach in Spain, due to well-established judicial practice and a solid legal framework, as well as the global acceptance and high number of States parties to the New York Convention. ${ }^{106}$

40. The reasons provided to stress the contrariness of the Provincial Court of Barcelona's decision against EU law and the doctrine of the CJEU are the following: first, the national law applicable to the validity of the jurisdiction agreement is the one applicable by the court where the parties submit their disputes according to Article 25(1) of the Brussels I Regulation (recast) (French law); second, the clause should in a form that accords with the usages of the shipping sector, as set out in Article 25(1)(c) of the Regulation, and domestic laws should not be an obstacle to these well-known practices, according to Trasporti Castelletti; third, there is no need to assess the acceptance of the choice of court clause in the $\mathrm{B} / \mathrm{L}$ once this is conveyed by the shipper to the consignee, including the choice of court agreement, according to Coreck Maritime; fourth, the negotiable character of the $\mathrm{B} / \mathrm{L}$ has been widely and globally accepted as part of the usages of the shipping sector since it was first recognised by English courts; fifth, the endorsee (Congemasa) should be entitled to the goods if he received the $\mathrm{B} / \mathrm{L}$ in good faith from the shipper (Empacreci) by endorsement; sixth, the purpose of the $\mathrm{B} / \mathrm{L}$ is to transfer the clauses to the endorsee; and finally, the insurance company (Zurich) will be subrogated in the position of the endorsee and buyer (Congemasa) under French law; Zurich is not a mere third party that acts in good faith since it is subrogated in the rights and obligations of the endorsee.

41. The goal of the CJEU, as clarified in the TNT-AXA ${ }^{107}$ and the Nipponkoa ${ }^{108}$ cases involving the carriage of goods by road where the $\mathrm{CMR}^{109}$ applies, is to guarantee, in relation to the "national applicable law to verify the material validity of the choice of the forum agreements" in civil and commercial matters, "the free movement of judgments, the predictability as to the courts having jurisdiction", [...], the "sound administration of justice", reducing "the risk of parallel proceedings", and the "mutual trust in the administration of justice" in the EU. ${ }^{110}$ In conclusion, this author believes that the

\footnotetext{
${ }^{102}$ ES:APB:2016:5241A.

${ }^{103}$ The following judgments stress the prevalence of Article 25 of the Brussels I Regulation (recast) over Articles 468 and 251 SAMN: Order of the Provincial Court of Pontevedra No. 1 of 16 October 2017, ES:APPO:2017:3336A; Order of the Provincial Court of Cadiz No. 5 of 8 July 2019, ES:APCA:2019:36A; Order of the Provincial Court of Madrid No. 28 of 5 July 2019, ES:APM:2019:2555A; and Orders of the Provincial Court of Valencia No. 9 of 11 October 2019, ES:APV:2019:3478A, and 18 November 2019, ES:APV:2019:4632A.

${ }^{104}$ Belintxon Martin (note 58).

${ }^{105}$ A.-L. Calvo Caravaca and J. Carrascosa González (note 4), p. 775; Antón Juárez (note 2), pp. 232-235.

${ }^{106} \mathrm{Vid}$. ECHEBARRIA FERNÁNDEZ (note 57), p. 85 on the validity of arbitration clauses in favour of foreign arbitral tribunals under Spanish law according to the Law 60/2003 of 23 December on arbitration (Official State Gazette No. 309 of 26 December 2003) and Article II(2) (formal validity) of the International Convention on the Recognition and Enforcement of Foreign Arbitral Awards (New York Convention) of 10 June 1958, 330 UNTS 38.

${ }^{107}$ Judgment of the CJEU of 4 May 2010, TNT Express Nederland BV v Axa Versicherung AG, C-533/08 EU:C:2010:243, para. 49.

${ }_{108}$ Judgment of the CJEU of 19 December 2013, Nipponkoa Insurance Co (Europe) Ltd v Inter-Zuid Transport BV, Case C-452/12, EU:C:2013:858, para. [36].

${ }^{109}$ Convention of 19 May 1956 on the Contract for the International Carriage of Goods by Road (CMR), 399 UNTS 189 CMR.

${ }^{110}$ BelintXon Martin (note 58), pp. 128-130, cites regarding the goals set out by the SAMN: J. C. Fuente Gómez, "Principios y fines generales de la Ley de Navegación Marítima", in M. V. Petit Lavall and A. Puetz (Dirs.), La eficiencia del transporte como objetivo de la actuación de los poderes públicos: liberalización y responsabilidad, Marcial Pons, 2015, pp. 361-366; on
} 
judgment of 29 May 2020 and its line of argument attempt to establish a protectionist and restrictive system for the conveyance of the $\mathrm{B} / \mathrm{L}$ to a third party $\mathrm{B} / \mathrm{L}$ holder, a 'forum exorbitantis' fuelled by the Spanish legislator that has no place from a commercial perspective. Furthermore, the judgment attempts to halt the European legislator's quest for harmonisation of national laws and trespasses the limits set out by the CJEU's doctrine. ${ }^{111}$

42. The European legislator not only failed to include any provisions on the transfer of jurisdiction clauses but also the so-called 'hybrid' dispute resolution clauses in the Brussels I Regulation (recast), as some scholars have pointed out. ${ }^{112}$ As previously expressed in this commentary, English law and jurisdiction are among the most sought after by parties engaged in the carriage of goods by sea. Many standard charterparty and B/L forms include these among their clauses. No agreement had been reached between the UK and the EU at the time this commentary was drafted. However, it is clear that from 1 January 2021, EU law and thus the Brussels I Regulation (recast) will cease to apply in the UK for any disputes commencing after the transition period established by the EU Withdrawal Agreement expires. Regrettably, Spanish courts will cease to apply Article 25 of the Brussels I Regulation (recast) to submission clauses in favour of English courts, with several implications for case or cargo claim disputes. A new agreement will probably pave the way for the continuity of business as usual for legal operators. However, the rules already analysed, namely Article 22 SOLJ, will determine the conditions for the validity of choice of court agreements in favour of English tribunals and thus Articles 468 and 251 SAMN will set up the conditions for their validity and the conveyance of the $\mathrm{B} / \mathrm{L}$ to the endorsee who is not privy to the shipper and the carrier's contract. Overall, there will be no room for discrepancies in this case regarding the law applicable to the conveyance of a $\mathrm{B} / \mathrm{L}$ containing a jurisdiction clause for the endorsee.

\footnotetext{
the drafts and 'travaux préparatoires' of the SAMN, see J. L. GoÑ ETCHEVERs, Temas de Derecho Maritimo, Thomson Reuters Aranzadi, 2016, p. 383 et seq.

${ }^{111}$ Y. Reinhard, I. Bon-Garcin, and M. Bernadet, Droit des transports, Dalloz, 2010, pp. 2 et seq.; BelintXon Martin (note 58), and also from the same author, "Human Rights and Corporate Social Responsibility in Transport Companies. A Note on European Law", Cuadernos Europeos de Deusto / Deusto Journal of European Studies, No. 63, 2020, pp. 269-294, at p. 273.

112 'Hybrid' dispute resolution clauses may include allowing the parties to choose between litigation or any alternative dispute resolution method (such as negotiation, mediation, conciliation or typically, arbitration); the agreement must refer to a transaction falling within the scope of application of the Brussels I Regulation (recast); ' $h y b r i d$ ' clauses can be unilateral (the claimant chooses where to sue) or asymmetrical (one party can choose between alternative dispute resolution and/or litigation, or between two or more courts); arbitration proceedings in London were allowed by the English Court of Appeal in an 'hybrid' agreement that provided for litigation in Brazil, where English law was effectively applied in spite of the choice of Brazilian law by the parties, in its judgment of 16 May 2012, Sulamerica CIA Nacional De Seguros SA \& Ors v. Enesa Engenharia SA \& Ors [2012] EWCA Civ. 638 (the case does not concern the Brussels I Regulation (recast)); the French 'Cour de cassation' recognises these clauses in the judgment of 7 October 2015, eBizcuss; contrarily, see its judgments 26 September 2012, Banque Rothschild, and 25 March 2015, Danne Holding; the French court reasoned that these clauses must satisfy the requirements of the judgment of the CJEU of 20 April 2016, Profit Investment SIM SpA v Stefano Ossi and Others, C-366/13, EU:C:2016:282, i.e. consent of the parties, predictability and sound administration of justice); ' hybrid' clauses are recognised in the Order of the Provincial Court of Madrid No. 28 of 18 October 2013, ES:APM:2013:1988A, the judgment of the High Court of 24 May [2013] EWHC 1328 (Comm), the judgment of Court of the State of Bremen (OLG Bremen) of 28 June 2006, SchiedsVZ, 2007, but not in the case of German Federal Court of Justice (BGH) of 24 September 1998 - III ZR 133/97, NJW, 1999, pp. 282-283; GómEZ JeNE believes that these 'hybrid' agreements should fall within the scope of Article 25 of the Brussels I Regulation (recast) if there is a valid litigation clause that complies with the formal and substantive requirements of the Regulation, although arbitration is excluded pursuant to Recital 12 and Article 1(2)(d); however, their applicability is doubtful under the Brussels regime; see M. GÓMEZ JENE, "El convenio arbitral: statu quo = The arbitration agreement: statu quo", CDT, Vol. 9, No. 2, 2017, pp. 7-38, pp. 25-27; see from the same author, "Las cláusulas de jurisdicción y arbitraje en la nueva Ley de Navegación Marítima", CDT, Vol. 6, No. 2, 2014, pp. 112-129, at p. 113; R. Fentiman agrees, vid. chapter 2, "Managing Litigation Risk", in International Commercial Litigation, $2^{\text {nd }}$ ed., OUP, 2015, pp. 41-123.
} 